\title{
Identifikasi dan Hitung Koloni Bakteri pada Tangan Perawat Kamar Operasi Instalasi Bedah Sentral (IBS) RSUD Arifin Achmad Pekanbaru Sebelum dan Sesudah Cuci Tangan dengan Antiseptik Klorheksidin Glukonat
}

\author{
Devi, ${ }^{1}$ Fauzia Andrini, ${ }^{2}$ Kuswan Ambar Pamungkas ${ }^{3}$
}

\begin{abstract}
Handwashing is an important thing to do and the most effective way in order to prevent nosocomial infection and infection control. The most popular surgery's handwashing is fuerbringer method. The purpose of this study was to know the effectivity of hand washing from the nurses that work at central operation theather Arifin Achmad General Hospital Pekanbaru before and after washing hand with chlorhexidine gluconat antiseptic. This study method was laboratoric descriptive with 22 samples which got from total sampling method. Bacterial was found from all sample. Bacterial which were found from the samples before hand washing were Coagulase negative staphylococci (CONS) (62.9\%), Bacillus sp (20\%), Metichillin resistant Staphylococcus aureus (MRSA) (11.4\%) and Metichillin sensitive

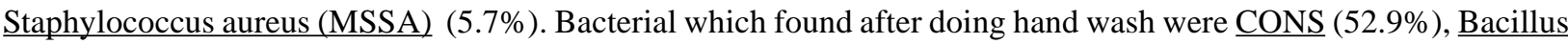
sp $(17.7 \%)$, Escherichia coli $(8.8 \%)$, MRSA $(11.8 \%)$, and MSSA $(5.9 \%)$. The result of this bacterial colonization area showed the reduction of bacterial colonization after doing hand wash in $90.1 \%$ sample, which mostly reduction was happen from II degree to I (36.4\%).
\end{abstract}

Keywords: Surgery's handwash, Bacterial examination, Chlorhexidine gluconat

Salah satu metode penyebaran infeksi terpenting pada sarana kesehatan adalah melalui tangan petugas kesehatan. Organisme patogen dari pasien yang terinfeksi atau dari lingkungan mengkontaminasi tangan petugas kesehatan selama aktifitas klinik dan kemudian mengkontaminasi ke pasien lainnya. ${ }^{1}$ Jumlah total bakteri yang terdapat pada tangan petugas medis bervariasi antara $3,9 \times 10^{4}$ Colony Forming Unit (CFU)/ $/ \mathrm{cm}^{2}$ hingga $4 \times 10^{6}$ $\mathrm{CFU} / \mathrm{cm}^{2}$. Jumlah ini meningkat seiring bertambahnya durasi aktifitas klinik., ${ }^{2,3}$

Cuci tangan dengan menggunakan sabun antiseptik yaitu tindakan yang paling efektif dalam upaya pencegahan kesakitan dan kematian akibat infeksi nosokomial pada lingkungan pelayanan kesehatan. Hasil penelitian membuktikan bahwa

\footnotetext{
1 Mahasiswa Fakultas Kedokteran Universitas Pekanbaru

2 Penulis untuk korespondensi : Bagian Mikrobiologi Fakultas Kedokteran Universitas Riau Pekanbaru,

3 SMF Bedah Fakultas Kedokteran Universitas Pekanbaru
}

cuci tangan dengan antiseptik dapat menurunkan jumlah kuman ditangan hingga 58\%.,5

Antiseptik yang ideal yaitu antiseptik harus bersifat mematikan bagi mikroorganisme pada pengenceran yang tinggi, tidak merusak jaringan atau benda mati, stabil, tidak mewarnai, tidak berbau dan bekerja cepat walaupun terdapat protein asing, eksudat atau serat-serat. ${ }^{6}$ Salah satu antiseptik yang banyak digunakan pada operasi adalah klorheksidin glukonat. Klorheksidin adalah biguanid yang mengandung dua muatan positif sebagai dikation yang mempunyai afinitas terhadap permukaan bermuatan negatif misalnya dinding sel mikrorganisme, polisakarida ekstraseluler mikroorganisme, hidroksiapatit, pelikel, plak, musin saliva dan mukosa mulut. Mekanisme kerja antiseptik ini adalah dengan cara mengganggu fungsi membran sel bakteri, denaturasi protein, memodifikasi fungsi kelompok protein dan asam nukleat. ${ }^{7}$ Klorheksidin aktif melawan mikroorganisme Gram positif dan negatif, ragi, 
jamur dan mikroorganisme fakultatif anaerob dan aerob. ${ }^{8}$

Peranan antiseptik pada dunia kedokteran khususnya di bidang pembedahan sangat besar. ${ }^{9}$ Cuci tangan bedah dilakukan sebelum dan sesudah melaksanakan semua tindakan bedah dan yang paling banyak digunakan berdasarkan prosedur dari Fuerbringer. ${ }^{10}$ Kamar operasi IBS RSUD Arifin Achmad Pekanbaru menggunakan tekhnik fuerbringer. Tindakan ini bertujuan untuk menghilangkan dan membunuh mikroorganisme transien dan mengurangi jumlah mikroorganisme residen untuk mengurangi risiko terjadinya kontaminasi pada luka operasi apabila sarung tangan yang di gunakan saat pembedahan robek. ${ }^{1,9}$

Berdasarkan uraian diatas, belum adanya data mengenai tindakan asepsis di kamar operasi IBS RSUD Arifin Achmad maka peneliti ingin mengidentifikasi dan mengetahui jumlah koloni bakteri pada tangan perawat kamar operasi IBS RSUD Arifin Achmad Pekanbaru sebelum dan sesudah cuci tangan dengan antiseptik klorheksidin glukonat.

\section{BAHAN DAN METODE}

Populasi adalah semua perawat kamar operasi IBS RSUD Arifin Achmad. Sampel pada penelitian ini adalah apus tangan perawat sebelum dan sesudah melakukan tindakan cuci tangan dengan menggunakan antiseptik klorheksidin glukonat yang memenuhi kriteria inklusi dan kriteria eksklusi. Penelitian ini bersifat deskriptif laboratorik yaitu mengidentifikasi dan mengetahui jumlah koloni bakteri pada tangan perawat kamar operasi IBS RSUD Arifin Achmad Pekanbaru, sebelum dan sesudah cuci tangan dengan klorheksidin glukonat. Pengambilan sampel dilakukan secara total sampling.

\section{Identifikasi Bakteri Sebelum dan Sesudah Cuci Tangan}

Pengambilan swab dilakukan sebelum cuci tangan pada perawat yang akan melaksanakan operasi pertama pada hari dilakukan pengambilan sampel dan sesudah cuci tangan dengan klorheksidin glukonat, dan teknik cuci tangan sesuai dengan petunjuk di kamar operasi IBS RSUD Arifin Achmad. Kapas lidi steril yang sudah dibasahi $\mathrm{NaCl}$ di $s w a b$ ke seluruh bagian tangan meliputi palmar, dorsal dan interdigiti dextra dan sinistra. Kapas lidi tersebut dimasukkan ke tabung reaksi yang berisi thioglikolat dan di bawa ke laboratorium Mikrobiologi FK UR.

Tabung thioglikolat yang berisi kapas lidi dimasukkan kedalam inkubator selama 24 jam pada suhu $37^{\circ} \mathrm{C}$. Setelah diinkubasi diperhatikan kekeruhan cairan thioglikolat. Pada thioglikolat yang keruh dilakukan swab ke permukaan agar darah dan dimasukkan kedalam inkubator selama 24 jam pada suhu $37^{\circ} \mathrm{C}$. Setelah agar darah diinkubasi, masing-masing koloni bakteri yang tumbuh pada media diidentifikasi secara makroskopis berdasarkan bentuk koloni, warna, bau, dan sifat hemolisis pada agar darah. Pemeriksaan mikroskopis dilakukan dengan pewarnaan Gram untuk identifikasi bakteri Gram positif menggunakan uji katalase, uji koagulase dan uji cefoxitine, dan untuk untuk indentifikasi bakteri Gram negatif dilakukan dengan reaksi biokimia.

\section{HASIL PENELITIAN}

Penelitian yang dilakukan secara deskriptif laboratorik di kamar operasi IBS RSUD Arifin Achmad Pekanbaru dan Laboratorium Mikrobiologi Fakultas Kedokteran Universitas Riau didapat jumlah sampel yang ada dan diperiksa pada penelitian ini sebanyak 22 orang.

\section{Gambaran Umum Sampel Penelitian}

Sampel pada penelitian ini adalah perawat kamar operasi IBS RSUD Arifin Achmad Pekanbaru yang membantu sebagai asisten dan instrumen serta menangani operasi pertama yang memenuhi kriteria berjumlah 22 orang (lampiran 2). Pengambilan sampel dilakukan secara total sampling. 
Tabel 1 Gambaran umum sampel penelitian

\begin{tabular}{llll}
\hline No & Ruang & Jumlah sampel & $\mathbf{\%}$ \\
\hline 1. & Kamar operasi 1 & 4 & 18,18 \\
2. & Kamar operasi 2 & 4 & 18,18 \\
3. & Kamar operasi 3 & 4 & 18,18 \\
4. & Kamar operasi 4 & 4 & 18,18 \\
5. & Kamar operasi 5 & 4 & 18,18 \\
6. & Kamar operasi 6 & 2 & 9,10 \\
\hline & Total & $\mathbf{2 2}$ & $\mathbf{1 0 0}$ \\
\hline
\end{tabular}

Tabel 1 menunjukkan bahwa jumlah sampel pada setiap ruangan sama kecuali kamar operasi 6 sesuai dengan penetapan fungsi setiap kamar operasi.

\section{Hasil Pemeriksaan Bakteriologi}

Secara umum, hasil pemeriksaan bakteriologi pada tangan perawat sebelum dan setelah mencuci tangan berdasarkan hasil identifikasi bakteri digambarkan pada tabel 2 dan tabel 3 :

Tabel 2 Hasil pemeriksaan bakteriologi pada tangan perawat sebelum cuci tangan

\begin{tabular}{llll}
\hline No & Bakteri & Frekuensi (n) & $\mathbf{\%}$ \\
\hline 1 & Escherichia coli & 0 & 0 \\
2 & Bacillus sp & 7 & 20 \\
3 & CONS & 22 & 62,9 \\
4 & MSSA & 2 & 5,7 \\
5 & MRSA & 4 & 11,4 \\
\hline & Total & $\mathbf{3 5}$ & $\mathbf{1 0 0}$ \\
\hline
\end{tabular}

Berdasarkan tabel 2 menunjukkan bahwa jenis bakteri terbanyak yang ditemukan pada pada tangan perawat sebelum mencuci tangan yaitu CONS dengan persentase $62,9 \%$, kemudian diikuti oleh
Bacillus sp dengan persentase $20 \%$, MRSA dengan persentase $11.4 \%$ dan MSSA dengan persentase $5,7 \%$. Dan dalam identifikasi bakteri ini ditemukan beberapa koloni bakteri pada 1 sampel.

Tabel 3 Hasil pemeriksaan bakteriologi pada tangan perawat sesudah cuci tangan

\begin{tabular}{llll}
\hline No & Bakteri & Frekuensi (n) & $\mathbf{\%}$ \\
\hline 1 & Escherichia coli & 3 & 8,8 \\
2 & Bacillus sp & 6 & 17,7 \\
3 & CONS & 18 & 52,9 \\
4 & MSSA & 2 & 5,9 \\
5 & MRSA & 4 & 11,8 \\
\hline & Total & $\mathbf{3 4}$ & $\mathbf{1 0 0}$ \\
\hline
\end{tabular}

Berdasarkan tabel 3 menunjukkan bahwa jenis bakteri terbanyak yang ditemukan pada pada tangan perawat sama dengan sebelum mencuci tangan yaitu CONS dengan persentase 52,9\%, kemudian diikuti oleh Bacillus sp dengan persentae 17,7\%, Escherichia coli dengan persentase $8,8 \%$, MRSA dengan persentase $11,8 \%$, dan MSSA dengan persentase $5,9 \%$.

Untuk hasil pemeriksaan bakteriologi pada tangan perawat sebelum dan sesudah cuci tangan berdasarkan derajat area pertumbuhan bakteri digambarkan pada tabel 4: 
Tabel 4 Gambaran perubahan derajat area bakteri setelah mencuci tangan $\quad(n=22$ orang)

\begin{tabular}{llll}
\hline No & $\begin{array}{l}\text { Perubahan der ajat area } \\
\text { pertumbuhan bakteri }\end{array}$ & $\begin{array}{l}\text { Sampel } \\
(\mathbf{n})\end{array}$ & $\begin{array}{l}\text { Per sentase } \\
(\%)\end{array}$ \\
\hline 1 & Derajat IV menjadi derajat III & 2 & 9,1 \\
& Derajat IV menjadi derajat II & 0 & 0 \\
& Derajat IV menjadi derajat I & 1 & 4,5 \\
2 & Derajat II menjadi derajat II & 6 & 27,3 \\
& Derajat II men ajdi derajat I & 3 & 13,6 \\
3 & Derajat II menjadi derajat I & 8 & 36,4 \\
& Derajat II tetap derajat II & 2 & 9,1 \\
\hline & Total & $\mathbf{2 2}$ & $\mathbf{1 0 0}$ \\
\hline
\end{tabular}

Berdasarkan tabel 4 tampak setelah sampel mencuci tangan terjadi penurunan derajat bakteri pada 20 orang sampel $(90,9 \%)$, yang tidak mengalami penurunan derajat pada 2 orang sampel $(9,1 \%)$. Penurunan terbanyak adalah dari derajat II menjadi derajat I pada 8 orang sampel $(36,4 \%)$. Pada penelitian ini tidak ditemukan adanya peningkatan derajat area pertumbuhan bakteri pada sampel setelah mencuci tangan. Hasil pemeriksaan bakteriologi, menunjukkan tindakan cuci tangan mampu mengurangi bakteri pada tangan perawat.

\section{PEMBAHASAN}

Berdasarkan hasil penelitian ditemukan bakteri di seluruh sampel $(100 \%)$ pada pemeriksaan bakteriologis sebelum mencuci tangan, dan sesudah mencuci tangan didapatkan penurunan derajat area pertumbuhan bakteri pada 20 sampel $(90,1 \%)$ serta tidak ditemukan sampel yang tidak ada bakteri. Untuk hasil identifikasi ditemukan bakteri CONS, Bacillus sp, Escherichia coli, MRSA, dan MSSA. Hal ini menunjukkan bahwa dari hasil pemeriksaan bakteriologi, tindakan cuci tangan bedah memiliki pengaruh terhadap bakteri pada tangan perawat.

\section{Hasil Pemeriksaan Bakteriologi Sebelum Mencuci Tangan.}

Identifikasi bakteri hasil pemeriksaan bakteriologi menunjukkan bahwa jenis bakteri terbanyak yang ditemukan pada pada tangan perawat sebelum mencuci tangan yaitu CONS $(62,9 \%)$ kemudian Bacillus sp (20\%), MRSA $(11,4 \%)$ dan $\operatorname{MSSA}(5,7 \%)$. Dalam pemeriksaan pada 1 sampel ditemukan lebih dari satu koloni bakteri, hal ini juga ditemukan pada hasil penelitian Sari W (2009) ${ }^{10}$ bakteri yang ditemukan dari tangan paramedis sebelum cuci tangan adalah kuman bentuk batang (KBB) Gram negatif, Staphylococcus sp, Bacillus sporoformik, Staphylococcus sp serta Pseudomonas $s p$ pada 1 spesimen.

Hasil pemeriksaan bakteriologi sebelum dilakukan prosedur mencuci tangan didapatkan bakteri pada semua tangan responden (100\%) dengan derajat area pertumbuhan yang bervariasi pada tiap responden dan ditemukan derajat area pertumbuhan bakteri terbanyak yaitu derajat II yang menunjukkan pertumbuhan bakteri sedang. Bakteri yang ditemukan di tangan responden, kemungkinan dapat diperoleh dari aktivitas klinis yang mereka lakukan berupa kontak dengan mikroorganisme yang menempel pada pasien yang memiliki daya tahan tubuh rendah, yang dapat menjadi tempat berkembangnya banyak mikroorganisme dibanding keadaan normal. Selain itu, bakteri yang diperoleh kemungkinan dapat berasal dari flora normal yang ada di tangan sampel atau dari udara dan bendabenda yang ada di lingkungan. Hasil penelitian ini sama dengan hasil penelitian Kamp G dan Kramer A (2004) $)^{11}$ sebagaimana yang dikutip dari Loho T dan Utami L (2007) ${ }^{11}$ menemukan bahwa jumlah bakteri pada tangan tenaga medis bervariasi. Jumlah bakteri meningkat seiring bertambahnya aktivitas klinik. Selain itu hasil penelitian ini sama dengan hasil penelitian Hayden MK (2000) ${ }^{12}$ sebagaimana dikutip dari Handayani dan Andrini F (2009) ${ }^{12}$ yang menyatakan bahwa lebih dari $41 \%$ sampel dari tangan petugas kesehatan ditemukan bakteri. 


\section{Hasil Pemeriksaan Bakteriologi Setelah Mencuci Tangan.}

Hasil pemeriksaan bakteriologi setelah dilakukan prosedur cuci tangan bedah pada penelitian ini ditemukan bakteri yang terbanyak yaitu CONS (52,9\%), kemudian Bacillus sp (17,7\%), Escherichia coli (8,8\%), MRSA (11,8\%), dan MSSA (5,9\%). Beberapa penelitian lain juga ditemukan bakteri setelah melakukan tindakan mencuci tangan, hasil penelitian Elfiani R (2011) ${ }^{13}$ menemukan bakteri Bacillus sp, CONS dan Enterobacter $s p$ pada tangan perawat setelah cuci tangan. Hasil Linjani D (2008) ${ }^{14}$ menemukan perawat yang pada tangannya saja teridentifikasi $S$. aureus $(43,75 \%)$ dan MRSA $(31,25 \%)$.

Untuk derajat area koloni bakteri ditemukan penurunan pertumbuhan bakteri pada 20 sampel (90,1\%), seperti terlampir pada tabel 4 Hasil yang didapat sangat relevan dengan tujuan dilakukannya cuci tangan yang menurut Craven dan Hirnle $(2000)^{15}$ tujuan cuci tangan adalah selain untuk mencegah transfer mikroorganisme dari lingkungan kepada pasien ke petugas kesehatan juga untuk menurunkan jumlah bakteri yang menetap maupun didapat pada tangan. Tindakan cuci tangan ini menggunakan antiseptik serta penggunaan alkohol setelah pembilasan dengan air.

Terdapatnya bakteri pada tindakan setelah cuci tangan bedah dan penurunan derajat area pertumbuhan bakteri yang tidak pada seluruh sampel kemungkinan disebabkan oleh salah satunya ialah tidak disiplinnya dalam melakukan prosedur tindakan cuci tangan bedah. Ward (2003) ${ }^{16}$ mengatakan bahwa sebagian besar infeksi nosokomial pada pelayanan kesehatan terjadi melalui transfer tangan petugas akibat kurangnya cuci tangan atau jeleknya praktek dalam proses cuci tangan dan pengeringan. Selain itu air dan alkohol juga menjadi penyebab kurang efektifnya terhadap penurunan bakteri. Hasil observasi peneliti, sumber air kamar operasi IBS bersumber dari air sumur bor dan langsung dialirkan ke wastafel. Untuk itu persyaratan air di kamar operasi IBS belum memenuhi, sesuai dengan keputusan Menteri Kesehatan Republik Indonesia sumber air dari PAM yang yang telah memenuhi syarat baku mutu air bersih, khusus untuk kamar operasi harus melewati proses filtrasi dan khusus untuk air cuci tangan operasi harus melalui water sterilization unit dengan UV (Ultra Violet) sebelum dialirkan ke keran-keran khusus cuci tangan. Sedangkan untuk pemakaian alkohol, teknik menggosok kedua tangan dengan alkohol sampai mengusap, biasanya memerlukan waktu 15-30 detik. ${ }^{12}$ Oleh karena alkohol membunuh mikroorganisme hanya jika terjadi kontak dengan kulit, maka penting untuk menggunakan alkohol dalam jumlah yang cukup (3-5ml) dan menyebar merata ke seluruh permukaan kulit. ${ }^{18}$

\section{KESIMPULAN}

Pada sampel sebelum cuci tangan bedah di temukan bakteri yaitu CONS (62,9\%), Bacillus (20\%), MRSA (11.4\%) dan MSSA (5,7\%). Dan bakteri yang ditemukan setelah cuci tangan bedah yaitu CONS (52,9\%), Bacillus sp (17,7\%), Escherichia coli $(8,8 \%)$, MRSA (11,8\%), dan MSSA $(5,9 \%)$. Pada sampel sebelum cuci tangan bedah diketahui bahwa ditemukan bakteri pada semua sampel bakteri dari tangan perawat dengan pertumbuhan bakteri terbanyak pada derajat II. Pada sampel sesudah cuci tangan bedah diketahui bahwa telah terjadi penurunan derajat area pertumbuhan bakteri $(90,1 \%)$. Penurunan terbanyak adalah dari derajat II menjadi derajat I yaitu pada 8 orang sampel.

\section{UCAPAN TERIMA KASIH}

Penulis ucapkan terima kasih kepada yang sebesar-besarnya kepada Fakultas Kedokteran Universitas Riau dan RSUD Arifin Ahmad Pekanbaru atas segala fasilitas dan kemudahan yang diberikan kepada penulis selama melaksanakan penelitian ini.

\section{DAFTAR PUSTAKA}

1. Anonymous. Basic concepts and practice: hand hygiene. International Federation of Infection Control. [cited 5 October 2011]. Available from: www/ ific.narod.ru/manual/hands. Htm.

2. Kampf G, Kramer A. Epidemiologic background of hand hygiene and evaluation of the most important agents for scrubs and rubs. Clin Microbial Rev. 2004; 17(4): 863-93. 
3. Girou E, Loyeau S, Legrand P, Oppien F, BrunBuisson C. Efficacy of handsrubbing wih alcohol based solution versus standard handwashing with antiseptic soap: randomized clinical trial. B Med J. 2002; 352: 362-8.

4. Asrin, Ratifah, Marsum. Efektifitas antiseptik kimiawi dan madu untuk cuci tangan dalam upaya penurunan jumlah bakteri. Mandala of Health Journal. 2006 Mei 2; 2: 33-41.

5. Rachmawati FJ, Triyana SY. Perbandingan angka kuman pada cuci tangan dengan beberapa bahan sebagai standarisasi kerja di laboratorium mikrobiologi Fakultas Kedokteran Universitas Islam Indonesia. Jurnal Logika. 2008 Agustus 1; 5(1): 1-13.

6. Suswati E. Efek hambatan triklosan $2 \%$ terhadap pertumbuhan Methicillin Resistant Staphylococcus aureus (MRSA). Biomedis. 2003 November 1; 1: 1-10

7. Joklik WK., Willet HP., Amos DP., Wilfret CM. Zinser Microbiology, 19th edition, Appetoncentury Crofts. New York; 1988. 533-55.

8. Martindale. The Ekstra Pharmacopoeia, 31th ed. Baltimore, The William \& Wilkins Company. USA; 1996. 1111-149.

9. Nichols, W.K. Anti Infectives. The Science and Pharmacy. Mack Publishing Company. USA; 1995. 1263-71.

10.Sari W. Efektivitas Larutan Antiseptik Klorheksidin Glukonat 0,5\% yang Tergenang untuk Cuci Tangan [skripsi]. Jakarta: Fakultas Kedokteran Universitas YARSI; 2009
11. Volk, Wheeler. Mikrobiologi Dasar. Edisi V. Jakarta: Erlangga; 1993. 234-45.

12. Susanti W.L. Efektivitas Sabun Cair Cuci Tangan Berbahan Aktif Triklosan Terhadap Bakteri pada Tangan Perawat Ruang Perawatan Bedah RSUD Arifin Achmad Pekanbaru [skripsi]. Pekanbaru: Fakultas Kedokteran Universitas Riau; 2011

13.Elfiani R. Pemeriksaan Bakterioogi Lingkungan dan Peralatan Medis yang Berpotensi Menyebabkan Infeksi Nosokomial di Ruang Neonatal Intensive Care Unit (NICU) RSUD Arifin Achmad Pekanbaru [skripsi]. Pekanbaru: Fakultas Kedokteran Universitas Riau; 2011.

14.Linjani D. Identifikasi Metichillin Resistant Staphylococcus aureus (MRSA) pada Hidung dan Tangan Perawat Ruang Perawatan Bedah Cendrawasih I RSUD Arifin Achmad Pekanbaru [skripsi]. Pekanbaru: Fakultas Kedokteran Universitas Riau; 2008

15.Craven, R.F \& C.J. Hirnle. Fundamental or nursing : Human health and function. Lipincott William \& Wilkins. Philadelphia. 2000.

16.Ward, D. Improving patient hand hygiene. Nursing Standard. 2003. 17 (35): 39-42.

17.Dinas Kesehatan Republik Indonesia. Keputusan Menteri Kesehatan Republik Indonesia Nomor: 1204/MENKES/SK/X/2004 Tentang Persyaratan Kesehatan Lingkungan Rumah Sakit dan pedoman penyelenggaraan pelayanan rumah sakit. 2008

18.Trampuz, Andrej and Widmer, A.F. Hand Hygiene: A Frequently Missed Livesaving Opportunity During Patinet Care, Mayo Clinic Proceedings. 2004. 79: 109-116. 